\title{
Competition before cooperation at US superconductor conference
}

Washington

President Ronald Reagan's administration is taking the promise of the newly discovered high-temperature superconductors seriously. The president himself will give the keynote address at the Federal Conference on Commercial Applications of Superconductivity being held in Washington DC this week steps have also been taken to stop foreign officials and company representatives attending.

The latter move was greeted with some surprise by embassy science officials, who are normally welcome as observers at scientific conferences. Although some have found ways of sneaking staff into the conference, most have been forced to accept that attendance is by invitation only and is intended to help US industry gain an edge in the world-wide race to commercialize the new superconductors. The conference is sponsored by the White House and the Department of Energy.

Whether anyone has "sat down and calculated the costs and benefits of such a policy" is open to doubt according to Robert Parks, director of the Washington office of the American Physical Society. Although major new research results are

\section{New UK centre for superconductors}

\section{London}

BrITISH universities have until 15 September to submit their bids to host the new "University and Inter-Institutional Research Centre" (URC) for hightemperature superconductivity. So says a letter sent to some universities by Professor E. W. J. (Bill) Mitchell, chairman of the Science and Engineering Research Council (SERC), who intends the centre should be allocated by the end of the year.

Although only one centre will be established, there will be collaboration between the host and other universities. The institutions invited to submit are Birmingham, Bristol, Cambridge, Durham, Imperial College London, Leeds, Liverpool, Oxford, Southampton, Strathclyde and Warwick. This centre is the first of several expected to be established soon (see Nature 328, 193; 1987).

At a recent meeting, SERC approved $\mathfrak{£ 7 0 0 , 0 0 0}$ from a delayed round of grant awards to be spent on superconductor research, and endorsed a $\mathfrak{1 3 - m i l l i o n}$ special initiative for the topic, $£ 1$ million of which would come from industry and/or the Department of Trade and Industry, plus $£ 1$ million each from the Science and Engineering Boards. Philip Campbell not expected to be announced at the conference, and foreign scientists will lose little by not attending, any step that appears to block the free flow of information may eventually work against the United States. An enormous amount of basic research remains to be done and will inevitably be hastened by international cooperation. Key discoveries have already come from Switzerland and Japan.

Despite the ban on attendance by foreign officials, no restrictions have been placed on foreign news reporters. Over 1,000 people, drawn largely from industry and government, are expected to attend the conference. After a brief introduction to the science of superconductivity from the University of Houston's Paul Chu and Nobel-prize winner Robert Schrieffer, they will spend most of their time hearing from government officials about the future applications of superconductors, the technological problems that need to be overcome and "foreign technological advances". One speaker will be missing. The Secretary of Commerce, Malcolm Baldrige, who was due to speak after the President, died after being thrown by a horse at the weekend.

Alun Anderson

\section{Positive Ariane tests greet motor redesign} Paris

Pronlems with the third-stage motor which have grounded Europe's Ariane space rocket for more than a year (see Nature 327,$267 ; 1987$ ) seem at last to have been overcome. Following successful tests by its manufacturers, Société Européene de Propulsion (SEP), the redesigned motor has now been fitted to the Ariane third stage, ready for shipment to the Kourou launch site in French Guiana. Provided that two further tests, on identical motors, are also positive, a launch date of 11 September was confirmed by Arianespace as "unofficial but realistic".

The final decision of whether to go ahead with the delayed V19 launch will be made at the end of August following further work. Meanwhile, the first two stages of Ariane have been taken out of storage and are being assembled at Kourou. The V19 launch will put the Australian AUSAT K3 and European ECS-4 satellites into orbit and is scheduled to be followed by two further launches this year. With 46 satellite launch contracts on its books, worth FF15,000 million (\$2,470 million), Arianespace needs to carry out 8 or 9 launches a year until 1990 to catch up on its backlog.

Peter Coles
US doubts over Soviet satellitelaunch services

\section{London}

SOVIET space experts are disputing a decision of the US State Department to forbid US companies to put commercial satellite payloads into orbit. The State Department says that the ban is to prevent advanced technology from falling into Soviet hands but the Soviet side (particularly the Glavkosmos organization) say the US objection is unfounded.

Glavkosmos, set up in 1985 to provide commercial launch facilities, has been discreetly making its facilities known to those who might otherwise have used US launching systems since the Challenger accident in January, 1986. The Soviet Proton rocket has been advertised as "highly reliable" and the new 2,000-tonne Energiya craft, which can deliver a 100tonne payload into orbit, is described as a "new generation" device. Launching fees

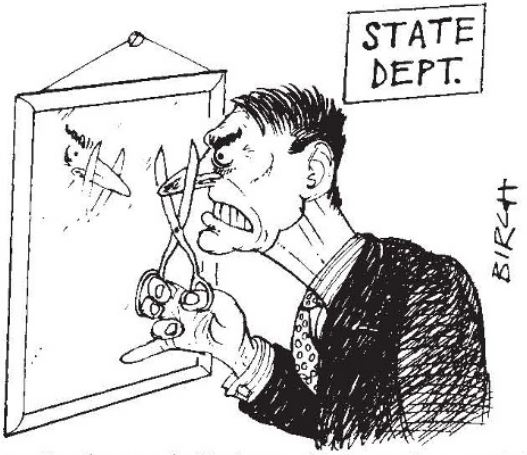

are "substantially lower" than those of the US National Aeronautics and Space Administration (NASA) or Arianespace - some say about half-price.

The Glavkosmos agency says that it can accommodate the reservations of potential customers. The authorities, it says, will waive customs inspection of satellites, and cautious customers could guard their satellites day and night until they reached their orbits. The agency says that if these concessions do not satisfy the State Department, it can only be that its embargo is political in origin.

The State Department, on the other hand, says that Glavkosmos officials have been "clearly informed" of the "longstanding" US rules that make the use of Soviet facilities by US companies impossible, and says that the Soviet side has also been told that no change of this policy is contemplated in the foreseeable future.

Even so, the backlog of commercial launches built up in the wake of the Challenger accident may offer some hope for Glavkosmos. Between 60 and 70 commercial satellites, valued at $\$ 7,000 \mathrm{mil}-$ lion, are believed to be stranded on the ground for lack of launchers. Vera Rich 